\title{
Political Factors of Process of European Integration of Turkey
}

\author{
Liana I. Mankova ${ }^{1}$ \\ ${ }^{1}$ Kazan (Volga Region) of Federal University, Kazan, Russia \\ Correspondence: Liana I. Mankova, Kazan (Volga Region) Federal University, 420008, Kazan, Kremlyovskaya \\ Street 18, Russia. E-mail: Liana-23-23@mail.ru
}

Received: June 15, 2015 Accepted: June 24, 2015 Online Published: June 30, 2015

doi:10.5539/jsd.v8n7p55 URL: http://dx.doi.org/10.5539/jsd.v8n7p55

\begin{abstract}
For decades Turkey has been one of the most important issues of European policy in the European Union (EU). This issue has no specific solutions. The purpose of this article is to identify and analyze the factors that impede the entry of Turkey into the European Union, as well as the establishment and explanation of the significant moments in the relations between the parties, which turned out to be the key ones in the world politics. The leading method in the research is a historical-comparative one, which on the basis of selected sources allows to compare and analyze the different milestones in the development of relations between the EU and Turkey. The article presents the analysis of the peculiarities of the relations of the European Union and Turkey, as in the general political aspect, and in some areas, taking into account the fact that each of the parties pursuing its own benefit and purpose. The data of the article may be useful in researches connected with the political history of Turkey as well as in contemporary socio-political discussions about a potential place of Turkey in the EU.
\end{abstract}

Keywords: EU, Europeanization, the Republic of Turkey, Copenhagen criteria, summit, agreement

\section{Introduction}

\subsection{Importance of the Problem}

Turkey persistently tries to join the European Union for over half a century. Within this time Turkey has undertaken a number of reforms in the political, economic and social spheres. It is necessary to note that as a result of these actions Turkey became closer to the EU, but the prospect of its full membership in the organization is still illusory. Only by 1999, Turkey managed to achieve recognition of the status of the EU candidate (Hajiyev, 2006). However, the steps for the further rapprochement of the parties have been postponed on a number of reasons. At the same time active reforms in the country made it possible to start in 2005 negotiations on Turkey's accession to the EU, which marked a new stage of development of modern interaction between the parties. The relations between Turkey and the EU (up to 1992 UES) are one of the most important and urgent items of Turkey's policy (Ortayl1, 2011). This is due to the fact that Turkey's attempts to become a full member of the EU suggest that the country's policy focused on Europe is a priority (Ezegodnyi, 2015).

\subsection{Explore Importance of the Problem}

The annual "progress reports" issued by EU experts give the analysis of the level of preparedness of the countries - candidates for EU membership to become full members of the organization. The report presented in 2011 put forward the position of the EU to the countries willing to join the EU (Ezegodnyi, 2015). This does not mean that the conditions for all countries seeking to enter the EU are the same. For each country a separate list of requirements, taking into account the economic and political situation in the country is set up. There are Copenhagen criteria used in the report for characterization the prospects of Turkey's accession (Ziganshina, 2005). At the Helsinki Summit in 1999 there were announced additional requirements for Turkey. The main point was the decision of the problems with Cyprus peacefully. The EU Council also guaranteed assistance in resolving this issue at the support of the United Nations.

\subsection{Criteria for Entry into the $E U$}

1. The deficiency of the state budget shouldn't exceed 3\% of GDP

2. The public debt shouldn't exceed $60 \%$ of GDP.

3. The state has to participate within two years in settlement of exchange rates and adhere to rate of national currency on the predetermined level. 
4. The rate of inflation shouldn't exceed more than $1,5 \%$ of average value of three countries of the European Union with the fixed prices.

5. Long-term interest rates for the state bonds shouldn't exceed more than for $2 \%$ average value of the corresponding rates in the countries with the lowest inflation (Ezegodnyi, 2015).

\subsection{Status of the Problem}

1. It is necessary to remind that today Turkey is a candidate for full membership in the Union. All the EU criteria have already been made. Turkey has reached a high level of economic development (Doklad, 2015).

2. Now the EU is going through its best times. In Europe, the urgent problem of the economic crisis is an internal transformation and rearrangement. (Ünal, 2002) How will Europe look like in the future - it is also an open question. These processes take place against the background of Turkey, which, on the contrary, becomes monolithic and powerful. It is planned that by 2023 , Turkey will have a huge potential for a breakthrough in their European ambitions.

3. The main supporters of Turkey on the way to the EU are the USA and the UK. It is due to the fact that these countries are very interested in the penetration of Islam in Europe, as its restraining force.

4. As we said above, the main obstacle to Turkey's European integration remains the problem with Cyprus. But according to politicians, this problem could be solved by itself. This may happen, firstly, due to the bankruptcy of Cyprus. Secondly, Cyprus could be used as one of the centers of opposition to the situation in Syria. It is possible that the problems in Syria will not be solved immediately and go beyond the boundaries of conjugated areas. And it will be a signal for actions in Cyprus. Thus, the Cyprus problem will be solved by itself.

5. As we said earlier, the EU has now a lot of problems. For this reason, there is no time to think either of Turkey or expansion to Eastern Europe. In fact the situation is deadlock. Even the program of "Eastern Partnership" seems very problematic. But it can be profitable for Turkey because it has strengthened relations with the Eastern partners of the European Union long ago. Now we mean here the Balkans and the Black Sea region. The aim of the Black Sea region is to preserve its position in European integration, at the same time retain its independence from Russia. For example, the weaker the relations of Georgia or Ukraine with Russia, the stronger they are with Turkey.

\subsection{Scientific Novelty of the Study}

The scientific novelty of this paper is that we will look at the issue of the relationship of the European alliance and Turkey through the analysis of contemporary, but not sufficiently investigated texts of international treaties and agreements in the Russian, Turkish and English languages.

\section{Materials and Methods}

\subsection{The Objectives of the Study}

In the study, the following tasks were solved: 1) to evaluate the results of the development of the relations of the parties since the formation of UES up to the present day; 2) to establish and explain the significant moments in the relations between the parties, which turned out to be the key ones to world politics, and 3) to identify the factors that impede the entry of Turkey into the European Union.

\subsection{Theoretical Methods}

To test the hypothesis different complex methods, complementing each other were used:

- theoretical - the analysis of literature, regulatory, legislative, instructional and teaching, working papers and mass media materials on the problem of research; studying and generalization of innovative historical analysis, synthesis;

\subsection{Base of the Research}

The basis of the study was the documentation of the European Union, with the analysis of the relations with Turkey included into the collection of documents published in the Official Journal of the European Communities; statistics of international economic organizations; interviews of famous politicians.

\subsection{Analysis and Steps in Research}

The study was conducted in two stages:

- International mass media pay a great attention to the development of relations between Turkey and the European Union. We selected the most informative and significant materials, analyzed them and reviewed the reports of political leaders at the international conferences. 
- The collected materials were translated from Turkish and English into Russian.

\subsection{Evaluation Criteria}

According to the speeches of such politicians like N. Sarkozy, A. Merkel, M. Ferbera it is seen their negative attitude to the possibility of joining Turkey the European Union. They often tend to focus on some of the shortcomings of the economy of the country and pay attention to the political and territorial development of Turkey historically different from European one. Having studied a number of the international treaties which came into force, nevertheless it is possible to trace the positive moments in the solution of the matter. In the Annual report of the EU on prospects about political cooperation for 2008 it is said that on condition of implementation of some requirements (Turkey can carry out without effort and damage to its policy) in respect of economy and foreign policy, Turkey will be unconditionally accepted into the European Union that will bring this organization new ideas and new forces.

\section{Results}

\subsection{The Major Factors Interfering the Entry of Turkey into the EU}

1. Recognition of unified Cyprus is the main demand of the EU to Ankara (Kudryashova, 2010). But Turkish government hesitates to take a decision, as it believes that having lost the influence in the north of Cyprus, it will lose its strategic potential. Turkey says that in case of recognition of Cyprus its national security system will be undermined. International experts speculate that if the Cyprus problem will not be solved in a positive way, then the way to the European Union for Ankara will be closed. But if to consider the fact that the history of the problem and its specifics is very complicated, and the relations between the two countries are far from friendly, the outcome of the situation is a long term problem. Perhaps the Cyprus problem will continue to be a weak point in Turkish foreign policy. On March 4, 2013, the Prime Minister of Turkey Tayip Erdogan at a joint press conference with his Greek counterpart, Antonis Samaras of Greece suggested to solve this problem with the "rich" history together. In his speech he invited to solve this problem. At the summit between Turkey and Greece 25 important intergovernmental documents were signed. The Prime Minister Erdogan said that the solution of the Cyprus problem, due to which Turkey is not yet in the EU, will remove many barriers for Ankara. At the same time, the solution of the problem will be a welcome result for the establishment of the necessary security, stability and peace in the region.

2. The Armenian question for Turkey is not only a simple non-recognition of genocide. This fact touches upon the relations between the two countries. In 1988, Turkey as a result of active military actions in the region of Nagorny-Karabakh closed its border with Armenia. From that moment between the two countries there were not normal diplomatic relations. Economic and trade relations were maintained by participation of third countries. Turkey by economic blockade tried to put pressure on Armenia in the issue of genocide (Starchenko, 2002), while Armenia used a genocide factor as a way of influencing Ankara with the help of the EU and the USA. But both sides understood that it was the time to put an end to almost century hostility. The relationship began to normalize in 2007. In 2008, Gul paid a visit to Armenia, the result of which was the fact that the presidents of both countries recognized the need to improve relations. The EU supported this desire of the parties. The important date was October 11, 2009, when the foreign ministers of Turkey and Armenia, Davutoglu and Edward Nalbandian signed the protocols in Zurich on the Establishment of Diplomatic Relations and Protocol on Development of Bilateral Relations. The hostility between the two countries came to an end. Nevertheless, the political forces of the European Union continued to put pressure on Ankara in some areas. But it's worth noting that the European Union does not consider the problem of Armenian-Turkish relations as a high priority, but this factor could be the trump card against Turkey while joining the EU.

3. The Kurdish question is a heavy burden for Turkey. Turkey has always considered the Kurdish as a threat to territorial integrity of the country (Ulchenko, 2001). The main thing is that the EU approves the idea of searching the Kurdish problem solution in the Turkish parliament, and offers the ideas to reinforce concrete measures.

4. Among the claims of the European Union to Turkey remains such a factor as a very rapid growth of the Turkish population. Taking into consideration this fact, in case of joining the EU Turkey will become the country with the largest representation in the European Parliament and a big influx of Turkish migrants to the countries of the EU.

\subsection{Results of Fulfilling by Turkey the Requirements of the European Union}

Turkey sufficiently met all requirements of the EU and satisfied all the political criteria of Europe. In this connection, the EU is ready to start negotiations on the integration of Turkey into the EU. But the leadership of the European Commission notes that negotiations could take a long time, not less than $10-15$ years. And the 
success of Turkey in this matter is still not guaranteed. At this stage the measures of strengthening a cultural political dialogue between the parties are debated. There is no doubt that Turkey is still waiting for a long and difficult way to become a full member of the EU. The process of preparation for accession to the European Union may last till the middle of this century.

\subsection{Public Opinion of Turkish Citizens about the Studied Questions}

Numerous analyses in order to identify the relationship of the Turkish public to the idea of joining the EU are conducted. These analyses indicate that a substantial majority of the population supports the government in the idea of joining the EU. These figures are stable for many years. More than $70 \%$ of the population in 2004 acted with the approval of the idea. But then the process of internal political reforms slowed down. In addition, the lack of further progress in the negotiations and the general uncertainty of prospects for the country's accession to the EU significantly reduced performance statistics. The number of those who are for joining the EU achieved $40 \%$ in 2010 (Turan Mesud, 2008). There is no complete unanimity on this question. Many people are afraid of the negative consequences of Turkey's accession to the EU. The results of the survey indicate that $49 \%$ of the population support the sovereignty of their own country. They are against the reforms in the field of foreign policy and defense, yet $31 \%$ of people are not happy with the changes in the socio-economic sphere. Statistics shows that $13 \%$ of the population do not wish to lose its independence in the field of politics and culture. And finally, even more impressive figure - $62 \%$ of Turkish citizens believe that the EU shows injustice to Turkey, because there are always new demands to Turkey in comparison with the other countries - candidates to EU (Birinci, 2002)

\section{Discussions}

The problem studied has a relatively recent history but there are a lot of works on this subject made by Russian researchers. There are such authors as A.G. Hajiyev (2006), G.M. Ziganshin (2005), N.Y. Ulchenko (2001), Y.S. Kudryashov (2010), E.I. Urazova (2004). The views of local researchers on the topic of prospects for Turkey's accession to the EU are quite diverse.

Turkish researchers also carried out a lot of work on this problem. In our work, we analyzed the articles in the Turkish language of such authors as Ali Birinci (2002), Hasan Unal (2002), Ilber Ortayli (2011).

Next, we divided the examined and analyzed works and documents according to the following classification:

1) The documents of the EU. Documentation of the European Union, analyzing relations with Turkey, is in the collection of documents published in the Official Journal of the European Communities. Some documents of EC were taken from the official website of the European Union, presenting an analysis of the current events related to the activities of the European Union, up to date information about EU policy, European integration, the activity of its bodies.

2) Statistics (Statistical data of international economic organizations, the annual report of the international consulting firm Jones Lang La Salle).

3) Reports of politicians at the international conferences.

4) Interviews with famous politicians.

\section{Conclusion}

It is considered that the tendency for Europeanization was formed and became a leading course of Turkish foreign policy in the era of the Ottoman Empire (Urazova, 2004). The main vector of this policy was originally set to Europe. Thus, the question of integration into the EU for Turkey is important both from an economic point of view as well as from a historic point of view. It should be noted that in the course of the reforms related to the modernization of the country, accompanied by great difficulties and social upheavals, the Government of Turkey, following the course of European orientation, had to seek solutions to particular problems, concerning the relations between Turkey and the European Union.

Today, Turkey shows persistence and requests to identify specific conditions for the integration into the EU and fixing the specific dates for the accession to the EU as an equal member. Such a definition of the situation would give the country an extra motivation to follow a chosen course and to continue a reform policy. According to the situation Turkey has a very long and bumpy way towards full EU membership. There is no doubt, however, that a key geo-strategic position of Turkey, its special place in the Muslim and Turkic world, and strong ties with the Western countries make the question about the place of Turkey in the world today very debating and interesting. Today we can say with confidence that the integration of Turkey into the EU is not the aim of the country. It is much more valuable for the Turks that in the process of integration the European Union will play the role of 
external guarantor during the rapid economic growth to insure the country from a political crisis. That is why "big business "in Turkey supports the idea of joining the European Union.

Today, the Turkish society looks very secular. The media informing about the relations between Turkey and the EU always speak about Turkey as a country with a double character. Turkey combines two completely different countries. One country - completely secular, focused on the west, very progressive; and the other, on the contrary - Islamic, backward and does not recognize the novelty. On this basis, the European politicians were divided into two groups. The attitude of both groups to Turkey is not very friendly. The leaders of the first group believe that the possibility of Turkey's joining the EU contradicts the very idea of an alliance. The second group believes that the EU simply has to accept Turkey into its ranks. After all, Turkey will help to expand the EU's internal market. In addition, Turkey will supply with a skilled labour force in Europe. For European companies lack of labour force is an actual problem, as Europe becomes a victim of the rapid aging of the indigenous population. What would not the European Commission experts speak, promising once a full integration of Turkey, the union can not easily change its decision. In any case, Turkey does not intend to become an "ordinary European country". Since 1959, when Turkey applied for membership in the EU, it performs a step-by-step all of the requirements of Brussels (Troshev, 1997). Turkey takes all these difficulties and the process of rapprochement with the European Union as a tool for transformation into a great world power. If it is impossible to move towards Europe there is a reason to try to be "their" in the East. Everything is interconnected - if to strengthen the position in the East, there will be more opportunities to make negotiations with the West.

From the point of view of EU Europe has a sufficient number of claims to Turkey. But the "Cyprus problem" continues to be a stumbling block in relations between the EU and Turkey. Until now the Europeans are not willing to admit southern Cyprus, which is in power in Turkey. In the center of attention of the experts of the European Commission is also the theme of Armenian conflict. In October 2012, Chancellor Angela Merkel met with Turkish Prime Minister R.T. Erdogan. At this meeting the Prime Minister Erdogan did not hesitate to give the EU an ultimatum about the time frames of EU integration (Interveu, 2015). He formulated his position in the following sentence: "If the negotiations with Brussels will not succeed till 2023, Turkey will refuse to join the EU." As you might guess, the date was not chosen by chance, since in October 2023, Ankara will celebrate the 100th anniversary of the Republic. According to the Turkish strategy Turkey has to revive its influence in the West by 2023 and at the same time to expand its influence in Eurasia. European countries are very skeptical about the idea of Turkey's accession to the EU. We believe that Turkey will succeed in her desire.

\section{Acknowledgments}

The work is performed according to the Russian Government Program of Competitive Growth of Kazan Federal University.

\section{References}

Birinci, A. (2002). 1980 ve sonrası. Genel Türk Tarihi Ansiklopedisi (Vol. 9, pp. 129-137). Ankara.

Doklad chlena Evroparlamenta Markusa Ferbera na sammite stran-clenov ES 2010 g., (27 aprelya 2015). Oficial'nyi sait MID Turtsii. Retrieved April 27, 2015, from http://www.mfa.gov.tr/disisleri-bakani-davutoglu-openinform.ru/news/pursuit

Doklad ministra inostrannykh del Germanii F.V. Shtainmaiera na vstreche predstavitelei chlenov ES v Berline 2008 g. (27 aprelya 2015). Oficial'nyi sait MID Turtsii. Retrieved April 27, 2015, from http://www.mfa.gov.tr/default.tr.mfa

Ezegodnyi doklad ES o perspektivakh sotrudnicestva s Turtsiei za 2011g. (27 aprelya 2015). Oficial'nyi sait Evropeiskogo Soyuza. Retrieved April 27, 2015, from http://www.inosmi/europe/12009.html

Ezegodnyi doklad ES o perspektivakh politiceskogo sotrudnicestva s Turtsiei za 2011g. (27 aprelya 2015). Oficial'nyi sait Evropeiskogo Soyuza. Retrieved April 27, 2015, from http://www.inosmi.ru/europe/184813109.html

Ezegodnyi doklad ES o razvitii Turtsii za 2011g. (27 aprelya 2015). Retrieved from http://www.inosmi/europe/009817755.html

Gadzhiev, A. G. (2006). Period vstupleniya Turtsii v ES i Kopengagenskiye criterii. Sovremennaya Turtsiya: problem i resheniya. Moskva.

Interveu, R. T. (n.d.). Erdogana gazette “Vatan” 17.12.2011 №12. Retrieved April 27, 2015, from http://www.haber.gazetevatan gorusme-yapmadim/441559/1

Itogovyi document sammita stran-chlenov ES za 2010g., Retrieved April 27,2015 from 
http://europa.eu.biu.ac.il/Besa/meria/journalissuel/jvlnla3.html

Kudryasova, Eu. S. (Eds.). (2010). Turtsiya i Evropeiskii Soyuz: istoriya, problem i perspectivy vzaimodeistviya. Moskva.

Mesud, T. (2008). «Comparing Nationalist and Islamist Tradition in Turkish Politics». Retrieved from http://www.crinfo.org/citations/19615

Ortaylı, İ. (2011). Türkiye'nin Yakın Tarihi. In Avrupa yolunda Türkiye (pp. 141-146). Stanbul.

Otchet MVF "Perspectivy razvitiya mirovoi ekonomiki" za 2012g., Retrieved April 27, 2015, from http://www.imf.org

Programma Partii Spravedlivosti i Razvitiya Turtsii za 2012 g., Retrieved April 27, 2015, from http://www.akparti.org.tr/mobil/hedefler

Starchenkov, G. I. (2002). Turtsiya: dolgii put'v Evrosoyuz. Moskva

Troshev, G. (1997). Turtsiya. Sovremennye problem ekonomiki i politiki.Moskva.

Ulchenko, N. Eu. (2001). Torgovye otnosheniya Rossii i Turtsii: factory rosta i destabilizatsii. Moskva: Nauka.

Ünal, H. (2002). Türkiye-Avrupa birliği ilişkileri ve Türk-Yunan sorunları. Türkler Ansiklopedisi (Vol. 17, pp. 187-199). Ankara.

Urazova, E. I. (2004). Turtsiya 20 vek.Moskva.

Zigansina, G. M. (2005). Turtsiya i ES:sotzialno-pravovye i politiceskiye aspect integratzii. Moskva.

\section{Copyrights}

Copyright for this article is retained by the author(s), with first publication rights granted to the journal.

This is an open-access article distributed under the terms and conditions of the Creative Commons Attribution license (http://creativecommons.org/licenses/by/3.0/). 